Z. Klin. Chem. Klin. Biochem.

11. Jg. 1973, S. $388-392$

\title{
The Polypeptide Structure of Immunoglobulin: Experimental Studies on the Recombination of Radiolabelled Myeloma Polypeptide Chains1)
}

\author{
BY O. WETTER \\ Innere Klinik und Poliklinik (Tumorforschung) (Direktor: Prof. Dr. C. G.Scbmidt) der Gesamthochschule Essen
}

(Eingegangen am 10. Mai 1973)

Experiments using polypeptide chains of immunoglobulins ${ }^{2}$ ) have been performed by several authors to study the requirements of the formation of Ig molecules in vitro from the constituent $\mathrm{H}$ - and L-chains ${ }^{3}$ ). Where interest was focussed on chemical problems, myeloma proteins were used, owing to their ready accessibility in pure form and in sufficient quantity.

For the experiments described in this text chromatographically isolated IgG myeloma proteins were used. The percentage of recombined polypeptides was evaluated from the sedimentation pattern and from the starch gel electrophoresis of isolated H- and L-chains. In the experiments with $\mathrm{H}$-chains in the form of an exclusively fast sedimenting fraction $(9.5 \mathrm{~S})$, the percentage of recombined molecules was significantly smaller than in experiments using $\mathrm{H}$-chains in a non-aggregated form (4.6 S). The influence of the ratio of $H$ : $L$ chains in the recombination mixture was also studied and in accordançe with other authors a proportion of 3:1 was found to be most favorable with respect to the maximum regain of $\gamma$-globulin molecules.

Über Untersuchungen zum Studium des Rekombinationsverhaltens der H- und L-Polypeptidketten ${ }^{3}$ ) von Immunglobulinen ${ }^{2}$ ) ist verschiedentlich berichtet worden. Myelom-Proteine sind für diese Studien insbesondere dann verwendet worden, wenn die physiko-chemischen Bedingungen zur Rekombination interessierten. Die mühelose Gewinnung relativ großer Substanzmengen in reiner Form aus dem Blut von Myelom-Patienten bietet günstige Voraussetzungen für derartige Versuche in vitro.

Für die in der vorliegenden Arbeit dargestellten Untersuchungen wurden chromatographisch isolierte IgG-Paraproteine benutzt. Das Rekombinations-Ergebnis wurde unter Heranziehung des Ergebnisses der Sedimentationsanalyse in der Ultrazentrifuge und der StärkegelElektrophorese beurteilt. In den Experimenten mit H-Polypeptidketten, die ausschließlich eine schnell sedimentierende Komponente von 9,5 S aufwiesen, war der Prozentsatz rekombinierter Moleküle deutlich geringer als in Versuchen mit H-Ketten in nicht-aggregierter Form $(4,6 \mathrm{~S})$. Es wurde weiterhin der Einfluß des Verhältnisses von H-:L-Kette auf das Rekombinations-Ergebnis untersucht. In Übereinstimmung mit anderen Autoren wurde ein H:L-Verhältnis von 3:1 als optimal für die Rekonstitution von 7S- $\gamma$-Globulin-Molekülen gefunden.

Polypeptide chains obtained by the reduction of myeloma proteins show a strong tendency to recombine to a certain extent, even in heterologous mixtures, i. e., in mixtures of heavy (H-) and light (L-) chains from different myeloma proteins. This "unspecifity" of reconstitution of $\gamma$-globulin molecules has also been observed in mixtures of $\mathrm{H}$ - and L-chains of $\gamma$-globulins of different species (1). On the other hand, the specific recombination of autologous myeloma polypeptide chains has been demonstrated by preferential binding experiments (2) and optical rotatory dispersion measurements $(3,4)$. With respect to the considerable differences in heterologous recombination experiments with myeloma polypeptide chains found by other authors (2) and in own experiments (5) two points have to be considered:

1. a possible effect of the preparative procedures on the reactivity of $\mathrm{H}$ - and L-polypeptide chains,

2. the existence of structural features of $\mathrm{H}$ - and L-chains which might be related to antigenic properties of these chains and which might favour the formation of certain $\mathrm{H} / \mathrm{L}$-chain constellation during the recombination experiments.

The experiments described in the following have been performed with the intention of studying the recombi- nation conditions with respect to the quantitative regain of $7 \mathrm{~S}$-molecules, using ${ }^{125} \mathrm{I}$ - and ${ }^{131} \mathrm{I}$-labelled myeloma proteins.

\section{Materials and Methods}

The myeloma proteins He. and Sch. were isolated from the serum of two myeloma patients He. and Sch. In order to avoid alteration of the proteins as far as possible, chromatography on DEAESephadex A-50 were employed for the preparation. As lyophilization is often accompanied by a reduction of solubility the bulk of myeloma protein used for further treatment was used directly from the column eluate. Only the small portion for iodination was lyophilized.

Reductive cleavage and alkylation of the proteins was performed according to Fleischman et al (6). Separation of myeloma polypeptide chains was performed by gel filtration on Sephadex G-75 in $1 \mathrm{~mol} / \mathrm{l}$ propionic acid.

For the urea starch gel electrophoresis of reduced myeloma proteins the procedure given by SmIthiEs (7) was followed. Sedimentation analyses were done in the standard cell at $59780 \mathrm{rpm}$ and a phase-plate angle of $60^{\circ}$ in the analytical Spinco ultracentrifuge Model E.

Immunelectrophoresis was done according to SCHEIDEGGER (8). Antisera from Behring-Werke/Marburg were used:

1) This work was supported by Deutsche Forschungsgemeinschaft, Bad Godesberg.

2) abbreviated Ig.

3) $\mathrm{H}$ and $\mathrm{L}$ from heavy resp. light. 
Iodination of myeloma proteins He. and Sch. was performed according to MCCONAHEY and Drxon (9). $\mathrm{Na}^{131} \mathrm{I}$ and $\mathrm{Na}^{123} \mathrm{I}$ were obtained from Fa. Hoechst/Frankfurt'). The specific activity was $100-200 \mathrm{Ci} / \mathrm{mg}$ protein. An automatic liquid scintillation counter (Fa. Telefunken/Siemens) was used. $5 \mathrm{mg}$ of the iodinated material were mixed with about $300 \mathrm{mg}$ of the myeloma protein before reduction by mercaptoethanol.

For recombination, $\mathrm{H}$ - and L-chains isolated by gel filtration in $1 \mathrm{~mol} / \mathrm{l}$ propionic acid were mixed in the ratios $(H: L), 3: 1,4: 1$ and $2: 1$ and dialyzed against $0.15 \mathrm{~mol} / 1$ SøRENSEN phosphate buffer, pH 5.0.

The concentration of the fractions from gel filtration after recombination were calculated from their specific radioactivity.

\section{Results}

IgG myeloma protein He. and Sch. were isolated in an electrophoretically and immunoelectrophoretically pure form. Both proteins are of L-chains type $x$ and belong to $H$-chain subgroup $G_{1}{ }^{5}$ ).

The elution diagram of the reduced and alkylated protein He. on Sephadex G-75 showed 3 peaks (fig. 1). Immunoelectrophoretially material from fraction I and fraction II was identified by an anti- $\gamma$-chain antiserum; material from peak III was precipitated by an anti- $\%$ antiserum. Reduced and alkylated protein Sch. was eluted in 2 fractions (fig. 2). Fraction I did not form a precipitation line in the immunoelectrophoresis, fraction II was identified by an anti- $x$-antiserum.

The result of urea starch gel electrophoresis of these fractions is shown in figure 3. It may be seen that fraction I of protein He. reveals three bands, fraction II one strong component followed by a weak component and fraction III one band well in front of the fractions I and II.

Fractions I and II of the reduced myeloma protein Sch. were homogeneous, while fraction II again travelled well in front of fraction I. Sedimentation coefficients of fraction I, fraction II and fraction III-protein He. and

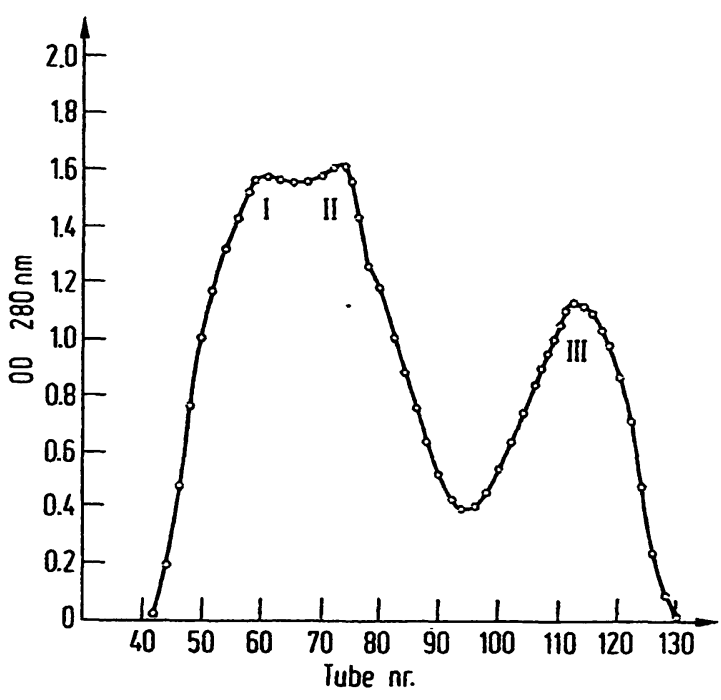

Fig. 1

Elution diagram of reduced alkylated $121 \mathrm{I}$-labelled myeloma protein He. on Sephadex G-75 in $1 \mathrm{~mol} / 1$ propionic acid

t) For the labelling of the proteins I am obliged to Dr. H. E. REIS, Essen.

5) We thank Dr. Trschendorr/Tübingen for the typing of $\mathrm{H}$-chain subgroup.

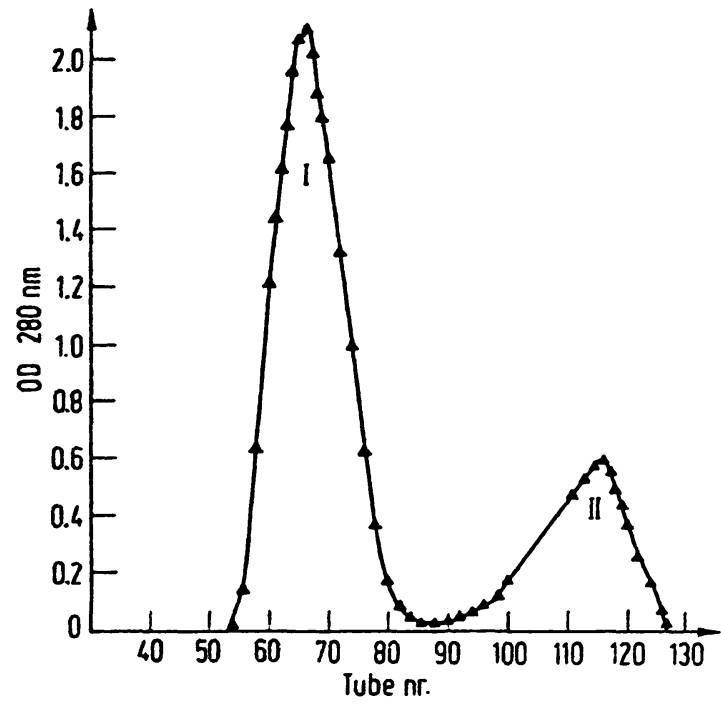

Fig. 2

Elution diagram of reduced alkylated $12 \%$-labelled myeloma protein Sch. on Sephadex G-75 in 1 mol/l propionic acid

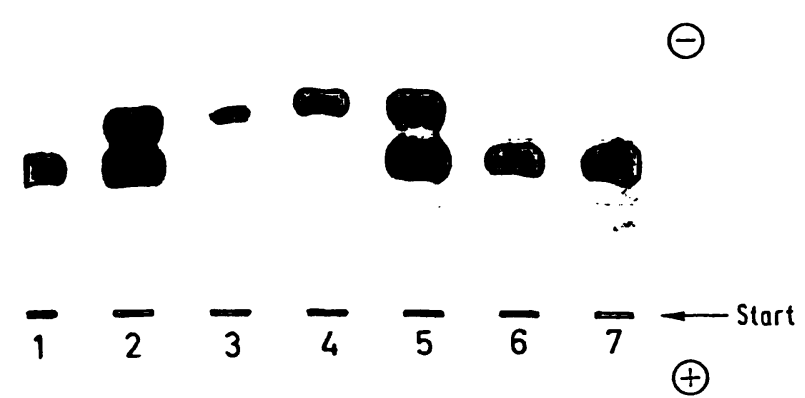

Fig. 3

Starch gel electrophoresis of fraction I (1), fraction II (3) of the reduced alkylated 121 (-labelled myeloma protein Sch. (2) and of fraction I (7)
fraction II (6), fraction III (4) of the reduced alkylated 131 -labelled myeloma protein He. (5)

Tab. 1

Sedimentation coefficients of $\mathrm{H}$-and $\mathrm{L}$-polypeptide chains of myeloma proteins He. and Sch. in $0.15 \mathrm{~mol} / \mathrm{l}$ phosphate buffer (SøRENSEN) pH 5.0

\begin{tabular}{cccccc}
\hline Myeloma protein & Sample & \multicolumn{4}{c}{$\begin{array}{c}\text { Sedimentation coefficients } \\
\text { (Svedberg units) }\end{array}$} \\
\hline He. & $\mathrm{H}^{2}$ & & 4.8 & 7.7 & \\
He. & $\mathrm{H}^{2}$ & 3.6 & & 9.6 \\
He. & $\mathrm{L}$ & 3.5 & & 9.5 \\
Sch. & $\mathrm{H}$ & 3.1 & & \\
Sch. & $\mathrm{L}$ & 3.1 & & & \\
\hline
\end{tabular}

fraction I and fraction II-protein Sch. are summarized in table 1. The result of gel filtration of a mixture of ${ }^{131} I-$ labelled $\mathrm{H}$-chains $\mathrm{He}$. of fraction $\mathrm{I}^{6}$ ) (fig. 1) and 125I-labelled L-chains Sch. is shown by figure $4.79 .3 \%$ of ${ }^{125} \mathrm{I}$-labelled L-chains Sch. appear together with $\mathrm{H}$ chains He. at tube No. 27/28. The result of gel filtration of the mixture of H-chains He. of fraction II (fig. 1) and L-chains Sch. is shown in figure 5.

$.92 .9 \%$ of the ${ }^{125}$ I-activity was diverted from the second peak (tube No. 42/43) to the first peak (tube No. 28/29). The result of gel filtration of a mixture of ${ }^{125}$ I-labelled $\mathrm{H}$-chains Sch. and ${ }^{131} \mathrm{I}$-labelled L-chains $\mathrm{He}$. is depicted in figure $6.56 \%$ of L-chains were found under the first 6) These $\mathrm{H}$-chains are designated $\mathrm{H}^{1}$, the $\mathrm{H}$-chains of fr. II (fig. 1) are designated $\mathrm{H}^{2}$. 


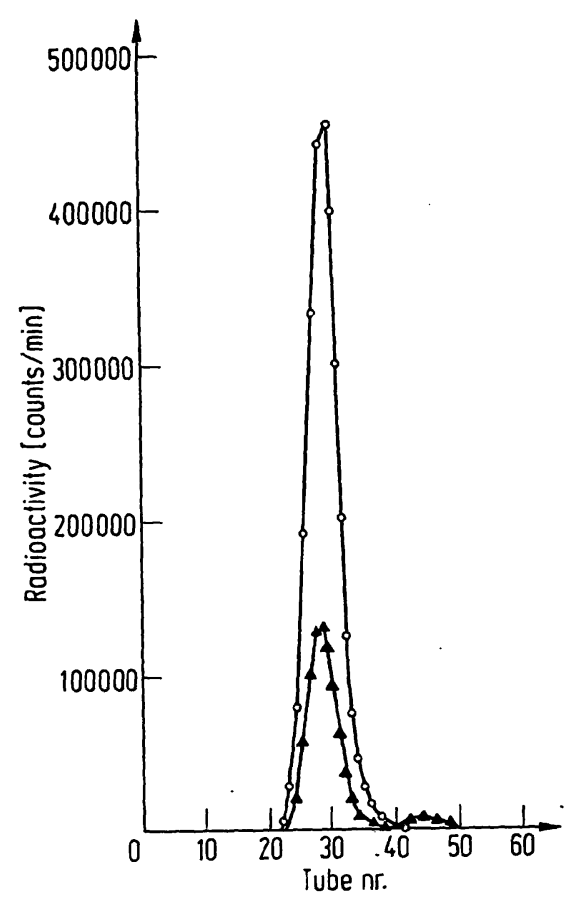

Fig. 4

Elution diagram of a mixture of ${ }^{131}$ I-labelled $\mathrm{H}^{1}$-chains $\mathrm{He}$ ( $(\mathrm{O})$ and of 125 -labelled L-chains Sch. (A) at the ratio $3: 1$ on a mass basis. of $12 \mathrm{~s}$-labelled L-chains Sch. (A) at the ratio $3: 1$ on a mass basis. Sephadex G-200 in $0.15 \mathrm{~mol} / 1$ SøRENSEN buf
recombination $91.6 \%$

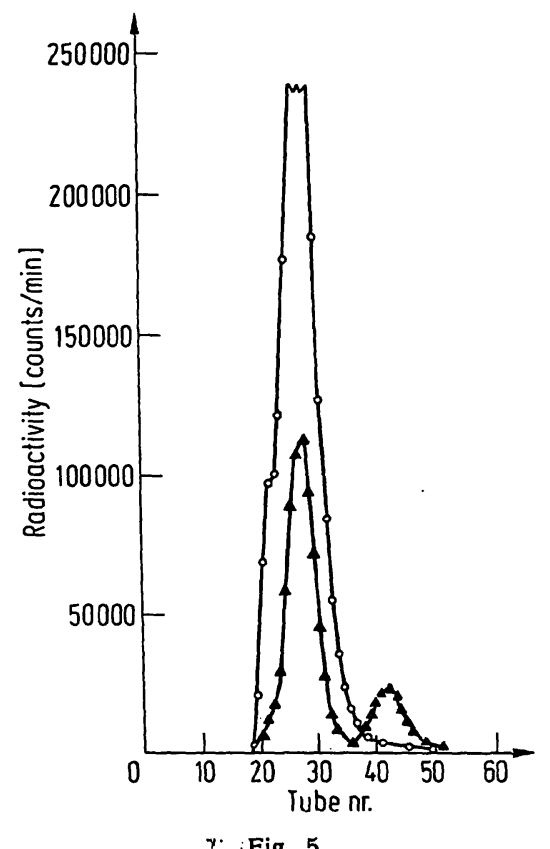

$\gamma \cdot$. Fig. 5

Elution diagram of a mixture of ${ }^{121} \mathrm{I}$-labelled $\mathrm{H}^{2}$-chains $\mathrm{He}$. in a polymeric state $(O)$ and ${ }^{125} \mathrm{I}$-labelled L-chains Sch. $(\Delta)$ at the ratio 3:1 on a mass basis. Sephadex G-200 in $0.15 \mathrm{~mol} / 1$ SøRENSEN buffer pH 5.0 . Extent of recombination $79.3 \%$

Tab. 2

Percentage of iodinated L-chains diverted from their original position in the G-200 elution diagram after mixing with H-chains

\begin{tabular}{ccc}
\hline $\begin{array}{c}\text { Mixture of chains } \\
\mathrm{H} / \mathrm{L}\end{array}$ & $\begin{array}{c}\text { Ratio of chains } \\
\mathrm{H}: \mathrm{L}\end{array}$ & $\begin{array}{c}\text { L-chain diversion } \\
\%\end{array}$ \\
\hline $\mathrm{He}^{1}$./Sch. & $3: 1$ & 79.3 \\
$\mathrm{He}^{2}$./Sch. & $3: 1$ & 92.9 \\
Sch./He. & $3: 1$ & 55.5 \\
Sch./He. & $4: 1$ & 41.6 \\
Sch./He. & $2: 1$ & 33.9 \\
\hline
\end{tabular}

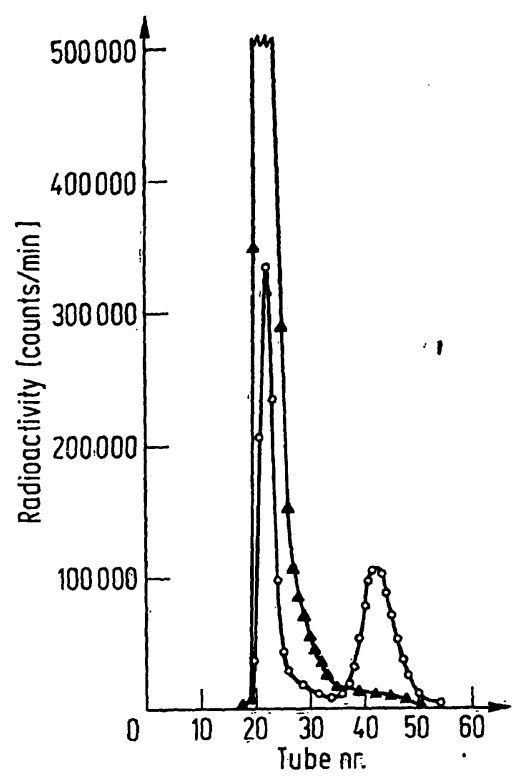

Fig. 6

Elution diagram of a mixture of 185 I-labelled H-chains Sch. $(\Delta)$ and 131I-labelled L-chains He. (O) at the ratio $3: 1$ on a mass basis. Sephadex G-200 in $0.15 \mathrm{~mol} / \mathrm{l}$ SøRENSEN buffer $\mathrm{pH}$ 5.0. Extent of recombination $\mathbf{5 5 . 5 \%}$

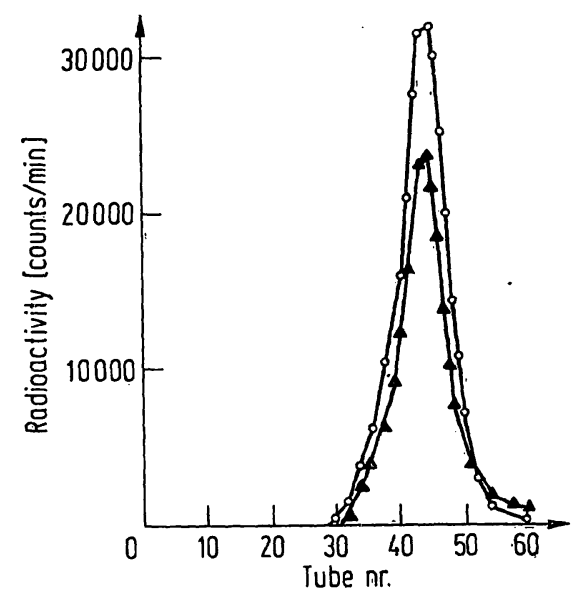

Fig. 7

Elution diagram of a mixture of ${ }^{125}$ I-labelled L-chains Sch. (A) and 131 I-labelled L-chaines He (O) at the ratio 1:1. Sephadex G-200 in $0.15 \mathrm{~mol} / \mathrm{l}$ SøRENSEN buffer $\mathrm{pH} 5.0$

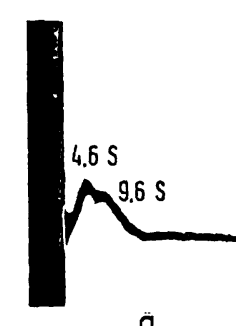

$\ddot{a}$

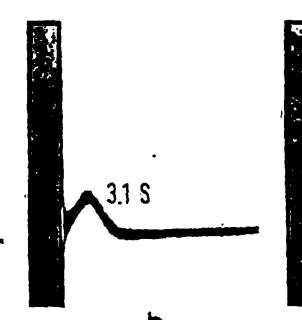

b
$6.6 \mathrm{~S}$

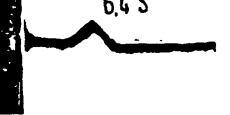

C
Fig. 8

Sedimentation analyses of $\mathrm{H}$-polypeptide chains $\left(\mathrm{H}^{2}\right)$ of myeloma protein He. (a), L-chains of myeloma protein Sch. (b) and of $a 3: 1$ mixture of these polypeptides (c) in 0.15 mol/1 SøRENSEN phosphate buffer, pH 5.0. (For details see text.) Direction of sedimentation process from the left to the right; protein concentration $(\mathrm{g} / \mathrm{l}): 2.8$ (a), 1.2
(b), 1.6 (c). Fotograph $9 \mathrm{~min} ., 24 \mathrm{~min}$. and 27 min. after reaching full speed.

peak (tube No. 22). The result of the gel filtration experiments are summarized in table 2.

L-chains $\mathrm{He}$. and Sch. did not interact under these conditions (fig. 7). 
$\Theta$

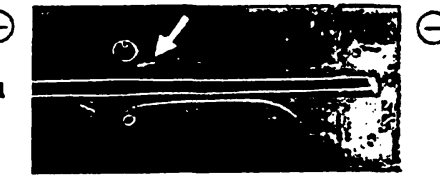

b

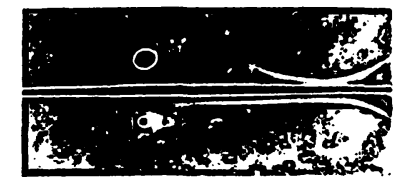

C

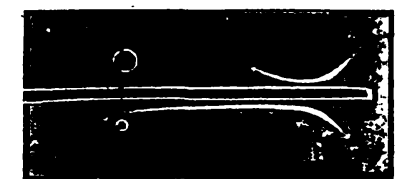

d

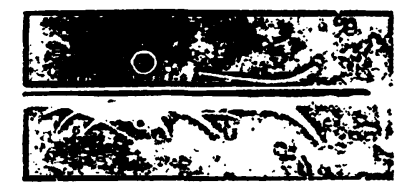

Fig. 9

Immunoelectrophoresis of H-chains He. (a), L-chains Sch. (b) recombined protein (c, d). Antisera: $a=$ anti- $\gamma$-chain, $b=$ anti-k-chain $c=$ anti-lgG, $d=$ anti-human; sample in the upper part, norma serum in the lower part of each plate. $\gamma$-Chain marked by the larrow.

The sedimentation analyses of the material resulting from recombination of $\mathrm{H}$-chains $\mathrm{He}^{2}$. and L-chains Sch. ( $\mathrm{He}^{2}$./Sch.) showed a single component of $6.4 \mathrm{~S}$. In figure 8 the result of sedimentation analyses of $\mathrm{H}$-chains $\left(\mathrm{He}^{2}\right.$.) and L-chains Sch. and of a mixture of these chains at the ratio of $3: 1$ are shown. The result of the immunoelectrophoresis is shown in figure 9.

\section{Discussion}

Whereas the elution diagram of the reduced and alkylated protein Sch. shows two peaks, that of protein He. reveals three components. By starch gel electrophoresis, it could be demonstrated that the two incompletely resolved peaks consist of $\mathrm{H}$-chains probably in some polymeric state. No L-chains could be detected in these components by immunoelectrophoresis.

Aggregation of $\mathrm{H}$-chains in buffers at neutral $\mathrm{pH}$ is one of the main obstacles in recombination experiments. Satisfactory results have been obtained by the use of a three step dialysis procedure (2). Recently a singlesolvent recombination procedure has been described, which takes advantage of the use of $0.004 \mathrm{~mol} / 1$ sodium acetate buffer at $\mathrm{pH} 5.4$ (10). In this solvent $\mathrm{H}$-chains of human IgG and myeloma protein were found to be stable up to three weeks in the cold as monodisperse dimers. In these experiments the proteins were prepared by precipitation with $1.6 \mathrm{~mol} / 1\left(\mathrm{NH}_{4}\right)_{2} \mathrm{SO}_{4}$ or by the method of CoHN (fraction II 1-2).
The myeloma proteins used in our experiments were isolated chromatographically and mixed with the small amount of material, which was lyophilized prior to iodination. In earlier recombination experiments (11) under the same conditions with lyophilized myeloma proteins, the yield of recombined polypeptides was about $40 \%$; this effect of lyophilization must be taken into consideration. Moreover it is remarkable, that very fast sedimenting components of $\sim 15 \mathrm{~S}$, as they had been observed with lyophilized proteins (12) did not appear with non-lyophilized proteins. As an aggregation of $\mathrm{H}$-chains to $17 \mathrm{~S}$ components can be achieved by adding sodium chloride to a final concentration of $0.1 \mathrm{~mol} / \mathrm{l}$ to $\gamma$-chains in a $0.004 \mathrm{~mol} / \mathrm{l}$ sodium acetate bifer (10), the tendency to aggregate seems to depend more on the nature or the state of the protein than on the ionic strength of the buffer. Otherwise one would expect the formation of the fast sedimenting components in the $0.15 \mathrm{~mol} / 1$ Sørensen phosphate buffer of nearly the same $\mathrm{pH}$. This is neither the case in H-chains prepared shortly after the reduction of the myeloma proteins, nor in preparations stored for 3 weeks in the cold.

Most probably the high recombination rate of $\sim 80$ or $90 \%$ is the consequence of this situation.

The sedimentation coefficients of the $\mathrm{H}^{1}$ - and $\mathrm{H}^{2}$-chain peak from gel filtration show predominantly a $4.8 \mathrm{~S}$ and a 4.6S component, respectively, which most probably consist of dimers of $\mathrm{H}$-chains. The $\mathrm{H}^{1}$-fraction may contain some material faster than $7.7 \mathrm{~S}$, which could not be measured, because of low concentration, but which might cause the elution profile (tab. 1).

The absence of a $4.6 \mathrm{~S}$ or $4.8 \mathrm{~S}$ component, i. e., H-chain dimers, in the H-chain material Sch. may explain the better recombination rate in the experiment $\mathrm{He}$./Sch. in comparison with the experiment Sch./He. A comparable regain of $7 \mathrm{~S}$-molecules has been observed by the abovementioned authors (10) using L-chains in an excess to $\mathrm{H}$-chains. As the results show, no L-chain exess is needed under the experimental conditions described here.

The antigenic behavior of the $6.4 \mathrm{~S}$ components, which resulted from recombination of $\mathrm{H}$ - and $\mathrm{L}$-chains is that of an IgG molecule (fig. 9).

The stability of these molecules should be based exclusively on non-covalent forces. This can be concluded from the result of a gel filtration experiment with a mixture of ${ }^{125}$ I-labelled L-chains Sch. and ${ }^{131}$ I-labelled L-chains $\mathrm{He}$ (fig. 7). No interaction can be detected as far as the formation of material is concerned, which is of the size of the $\gamma$-globulin molecule. This indicates that no reactive sulfhydryl groups remained after alkylation. 


\section{References}

1. Fougereau, M., Olins, D. E. \& Edelman, G. M. (1964), J. Exp. Med. 120, 349-358. - 2. GREY, H. M. \& MANNIK, M. (1965), J. Exp. Med. 122, 619-632. - 3. Dorrington, K. J., Zarlengo, M. H. \& TANFord, Ch. (1967), Proc. Nat. Acad. Sci. 58, 996-1003. - 4. WeTTER, O. (1969), Naturwissenschaften 56, 140-141. - 5. WeTTER, O., unpublished results. - 6. FLEISCHman, J. B., Pain, R. H. \& Porter, R. R. (1962), Arch. Biochem. Biophys. Suppl. 1, $174-180$. - 7. Smithies, O. (1959), Biochem. J.
71, 585-587. - 8. Scheidegger, I. I. (1955), Int. Arch. Allergy Appl. Immunol. 7, 103-110. - 9. McConafiex, P. J. \& Dixon, F. J. (1966), Int. Arch. Allergy Appl. Immunol. 29, 185-189. 10. Stevenson, G. T. \& Dorrington, K. I. (1970), Biochem. J. 118, 703-712. - 11. WetTrer, O. \& PFEIfFer, R., Acta Haematol. (in press). - 12. WETTER, O. (1969), Klin. Wochenscht. 47, $260-266$.

Prof. Dr. O. Wetter Innere Klinik u. Poliklinik (Tumorforschung) 43 Essen-Holsterhausen Hufelandstr. 55 